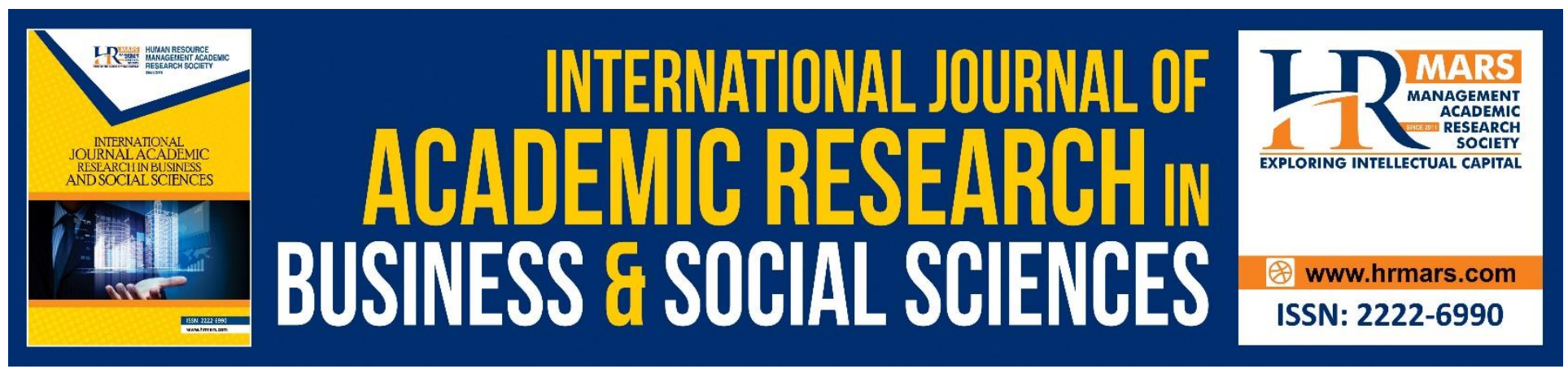

\title{
Does Flexibility affect the NPD Performance? A Malaysian Electrical and Electronics (E\&E) Industry Perspective
}

BakAun Teoh, Noor Hidayah Abu \& Roslan Jamaludin

To Link this Article: http://dx.doi.org/10.6007/IJARBSS/v8-i12/5253

DOI: $10.6007 /$ IJARBSS/v8-i12/5253

Received: 08 Oct 2018, Revised: 11 Dec 2018, Accepted: 30 Dec 2018

Published Online: 18 Jan 2019

In-Text Citation: (Teoh, Abu, \& Jamaludin, 2018)

To Cite this Article: Teoh, B., Abu, N. H., \& Jamaludin, R. (2018). Does Flexibility affect the NPD Performance? A Malaysian Electrical and Electronics (E\&E) Industry Perspective. International Journal of Academic Research in Business and Social Sciences, 8(12), 1498-1516.

\section{Copyright: (C) 2018 The Author(s)}

Published by Human Resource Management Academic Research Society (www.hrmars.com)

This article is published under the Creative Commons Attribution (CC BY 4.0) license. Anyone may reproduce, distribute, translate and create derivative works of this article (for both commercial and non-commercial purposes), subject to full attribution to the original publication and authors. The full terms of this license may be seen

at: http://creativecommons.org/licences/by/4.0/legalcode

Vol. 8, No. 12, 2018, Pg. 1498 - 1516

http://hrmars.com/index.php/pages/detail/IJARBSS

JOURNAL HOMEPAGE

Full Terms \& Conditions of access and use can be found at http://hrmars.com/index.php/pages/detail/publication-ethics 


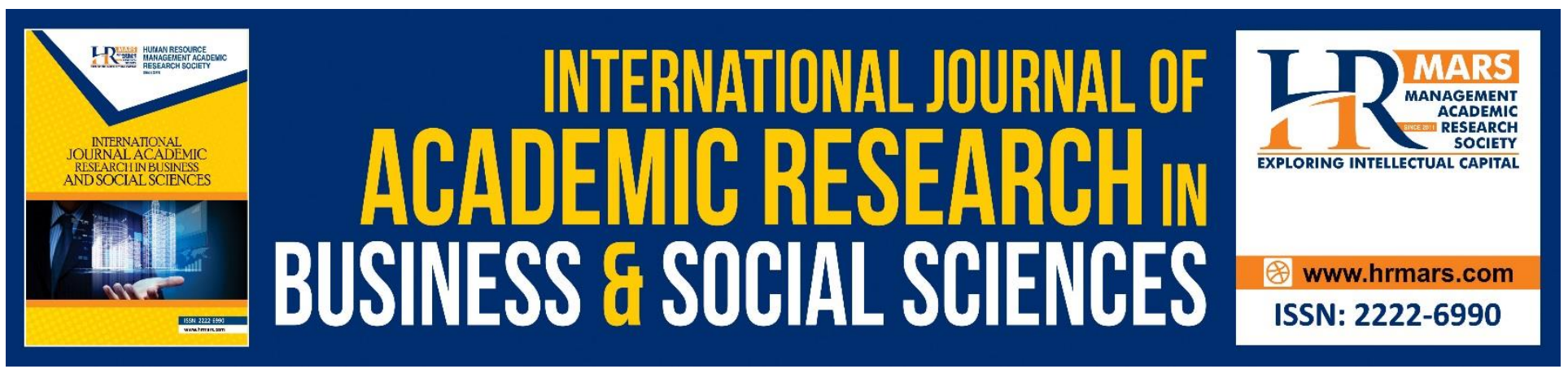

\title{
Does Flexibility affect the NPD Performance? A Malaysian Electrical and Electronics (E\&E) Industry Perspective
}

\author{
BakAun Teoh, Noor Hidayah Abu \& Roslan Jamaludin \\ School of Technology Management and Logistics \\ College of Business, Universiti Utara Malaysia, Sintok 06010 Kedah, Malaysia
}

\begin{abstract}
Main objective of the research is to develop the field of organizational performance by incorporating a wider scope of flexibility (MFD) aspects than is normally established in the NPD performance (NPP) literature. This survey-based paper is a confirmatory study using the resource-based theory, including 207 respondents with Malaysian electrical and electronics senior executives having mainly involved in development of new products. Five hypotheses were developed and analyzed statistically using multivariate approach. The results provided empirical evidences on how flexibility can be integrated holistically during development of new product. It suggests that successful leaders act as "integrating forces" on two levels: integrating the elements of corporate identity structures, and mediating between the corporate branding structures and the individual. The data used in this survey represent self-reporting by mainly the middle or top management in manufacturing organizations. Because of the chosen research approach, the research results may lack generalizability. This study would significantly contribute to the vibrant new product development of E\&E manufacturing industries in Malaysia. To further illustrate, this paper includes implications for manufacturing organizations to adapt flexibility in the development of new products. Besides, practitioners would make better decision by indulgencing the relationships, in addition to enable application of concepts in this research to other environment such as oil and gas or food manufacturing companies and the firm's decision makers would benefit from the findings of this research in this highly competitive and dynamic external business environment, in order to remain its competitive advantages over the competitors.
\end{abstract}

Keywords: NPD performance, electronics industry, manufacturing flexibility, Malaysia

\section{Introduction}

Thriving product development and design relied on internal and external factors in new product development. Therefore, both the factors aroused should be well-managed using scientific and 
logical approaches. Although both internal and external factors are the risks affecting to new product development project performances, the internal factors can be controllable and the external factors are very difficult to be controlled. In addition, manufacturing flexibility has been receiving attentions over the past decades as manufacturing flexibility-related functional capabilities are internal competencies and resources of the firm. Firm's manufacturing flexibility-related functional capabilities are competencies and resources of the firm and these elements are in consistency with the resource-based theory (Mills et. al., 2003). Through the previous decade, the concept of manufacturing flexibility has gained distinction among the researchers. Measurement of manufacturing flexibility would therefore helpful in identifying the relationship of manufacturing flexibility to the uncertainties in operation and early process design. Based on Mikell (2007), manufacturing is the transformation of materials into items of greater value by means of one or more processing and/ or assembly operations. Manufacturing is performed as a commercial activity by companies that sell product to customers. Manufacturing industries consist of enterprise and organizations that product or supply goods and services. In general, manufacturing sector is closely related to industrial design and engineering and manufacturing flexibility is the capability to have rapid change levels of production, quick and frequent new product development, and rapid respond to competitive threats.

There will be an endless improvement effort for Malaysia manufacturing sector to acquire the flexibility knowledge. Malaysia economy continues to expand despite the challenging external environment. New Economic Model (NEM) was launched in 2010 to ensure the country to achieve high income status and sustainable and inclusive growth by 2020. NEM is primarily driven by the involvement of private sector into value-added activities such as development of new product that helps in boosting Malaysia economy. Malaysia has high manufacturing production among the Asia Pacific countries which is feasible for development of new product. Aside, empirical effect of manufacturing flexibility on the performance is not persuasive even though it is used as the key competitive tool for businesses operating in vague and turbulent marketplace (Cesar and Ana, 2010). Organization's capability in developing a new product successfully has become critical than ever in point of growing intensity of competition and lessening product life cycles (Art et. al., 2010). Hence, there is a need to highlight for the manufacturing flexibility in Malaysia semiconductor industries.

\section{Literature Review}

Definition of Flexibility

Manufacturing flexibility is commonly identified as crucial competitive capability for many organizations and many previous studies have been conducted on the types of flexibility needed to satisfy various customer needs (Alan et. al., 2009). Besides, it helps a manufacturing firm to operate in unpredictable external environment and turbulent marketplace (Adegoke, 2005). Therefore, an organization should adopt flexible systems in production in order to have a better efficiency in terms of operation. Good manufacturing operations involve human capital, equipment and procedure that are designed with the integration of processes and materials (Mikell, 2007). According to Shewchuk (1999), flexibility has become one of the major favourable factors in modern manufacturing systems. There is an increased need for flexibility in manufacturing systems as it would decrease the product life cycle, shorter lead time to market and promote mass customization. Manufacturing flexibility 
INTERNATIONAL JOURNAL OF ACADEMIC RESEARCH IN BUSINESS AND SOCIAL SCIENCES

Vol. 8, No. 12, Dec, 2018, E-ISSN: 2222-6990 @ 2018 HRMARS

(MFD) has become widespread research title since 1990s (Larso et. al., 2009). Sethi and Sethi (1990) mentioned that a manufacturing system is flexible if the firm is capable to adapt extensive changes which are required to deals with the changes in environment.

\section{Flexibility in Malaysian Manufacturing Industries Context}

Schmenner and Tatikonda (2005) stated that the current information and digital era has supported the development of product with the introduction of new software namely computer-aided design (CAD) and computer-aided manufacturing (CAM), enhanced machine or tooling such as computer numerical control (CNC), flexible manufacturing systems (FMS) and robots, and computer integrated manufacturing information system like material requirements planning (MRP) manufacturing resource planning (MRP II). Flexibility provides the ability for an organization to cope with deviations in customer delivery demand, quicker introduction of new products and faster handling in product mix (Abdulkareem et. al., 2013). A firm's manufacturing flexibility is composed of various dimensions of flexibility and it is extensively recognised as a multi- dimensional concept (Larso et. al., 2009; Maike et. al., 2014; Roger and Mohan, 2005; Sethi and Sethi, 1990; Suarez et. al., 1996). Based on Berman and Sami (2005), flexibility components would include flexibility in organization, human resource flexibility, information technology flexibility.

Previous manufacturing flexibility studies were mostly conducted in urbanised countries such as United States (Nakata et. al., 2006), but not been conducted in emerging market and developing countries such as Malaysia. Besides, research conducted by Sari et. al. (2012) also accentuate the northern region of Malaysia, especially Penang, as one of the special economic regions or Free Trade Zone that emphasize on vigorous growing industrial hub, supply chain management, knowledge management and transfer, human resources and new product development. This has undoubtedly increased regional competitiveness and boosted the foreign investment in Malaysia. NCER has not only been seen as an important region to for promote domestics and international exports, but it also encourages for the growth of additional investment, new expertise and product transfers and generation of employment (Northern Corridor Economic Region, 2015). Hence, NCER, as the Silicon Valley of the East (Sari et. al., 2012), is a region would definitely be a conducive environment for conducting manufacturing flexibility (MFD) related activities. Through review of literatures, four dimensions of manufacturing flexibility are identified to be main dimensions of manufacturing flexibility that are relevant to Malaysia industries context. These four dimensions are new product flexibility, operation flexibility, machine flexibility, labour flexibility and material handling flexibility. These five new product related flexibility dimensions will often be referred as the term "manufacturing flexibility".

New Product Flexibility

New product flexibility (NPF) refers to the amount of varied new products introduced into a manufacturing system without experiencing huge fluctuations in terms of performance results (Koste and Malhotra, 1999). Based on Adegoke (2005), flexibility in new product is defined as the capability 
to introduce and manufacture brand new products or modify existing product. Suarez et. al. (1996) classified new product flexibility as the first-order flexibility that has direct impact to the competitive position of a company. Previous researches (Slack, 1991; Zhang et. al., 2003) also argued that volume and mix flexibility are the two most important of external driven manufacturing flexibility in terms of market competition (Alan et. al., 2009). However, new product and delivery flexibility are claimed as supportive consequential elements of manufacturing capabilities (Alan et. al., 2009; Maike et. al., 2014). Previous study conducted by Ilker and Birdogan (2011) focused on the antecedent factors such as R\&D strategy and product innovation type towards the small medium enterprises (SMEs) performance. Hence, there is a need to study the new product flexibility as a fundamental dimension in internally-driven flexibility dimensions in new product development stage across the Malaysia manufacturing industries.

\section{Operation Flexibility}

Operation flexibilities (OF) are deliberated as short-term flexibility (Alka et. al., 2013). Operation flexibility is the capability of a manufacturer to vary the production volume to compensate the changes in demand (Chryssolouris, 1996). Besides, operations flexibility is believed to have certain relationship with other flexibility dimensions such as machine, labour, material and routing flexibility (Chandrashekar, 1994). Hence, the operation flexibility is placed at the shop floor manufacturing functional level due to its relationships with the lower level dimensions (operational) and possible impact to dimensions at the higher level (overarching) (Larso et. al., 2009). According to Alan et. al. (2009), operation or process flexibility is an internally-driven dimension that "able to adjust and accommodate interruptions in manufacturing process such as variations in job or production scheduling". Moreover, study conducted by Alka et. al. (2013) focused on the relationship of operations capabilities towards performance in Australia airline industry context. Further studies should be carried out in manufacturing industry sectors where competitors have less regulatory limitations and have much greater scope in terms of competitive actions that they are willing to take. Hence, it would be valuable to conduct future studies across industry segments in developing and emerging countries to capture other contingency issues.

\section{Machine Flexibility}

According to Zubair et. al. (2001), machine flexibility (MF) is the machine selection that affects the immediate issues such as part grouping, machine and tool loading, part ratio selection and scheduling. The flexibility in machine has been demarcated in various contexts. Koste and Malhotra (1999) defined machine flexibility as the number of tasks a machine can execute without experiencing high alteration penalties in performance results. Machine flexibility is the capability to replace damaged or worn tools, changes in a tool magazine, and mount or assemble the required fixtures without intervened long setup times (Browne et. al., 1984). Machine flexibility also defined as the ability of the machine performing a task (Brill and Mandelbaum, 1990) or also known as machine capability (Benjaafar, 1994). Past researches revealed that the companies that have embraced flexible manufacturing systems (FMSs) were unable to link the definition given by Browne et. al. (1984) to their strategic objectives (Lim, 1987). Hence, a simpler definition given by Brill and 
INTERNATIONAL JOURNAL OF ACADEMIC RESEARCH IN BUSINESS AND SOCIAL SCIENCES

Vol. 8, No. 12, Dec, 2018, E-ISSN: 2222-6990 @ 2018 HRMARS

Mandelbaum (1990) may help in relating and ascertaining the machine flexibility in company strategic objectives, for instances, during the introduction of new products.

\section{Labour Flexibility}

According to Koste and Malhotra (1999), labour flexibility (LF) is the amount of operations or tasks a worker performs without experiencing high alteration penalties or huge fluctuations in performance results. Secondly, Adegoke (2005) also stated that the type of employment term is an important influential portion in determining the volume elasticity. This relates the type of labour capacity solutions that are used to achieve volume elasticity. The workers' skill level is also an influential aspect for achieving both mix and volume flexibility. For example, a multi-skilled labour is employee that would be able to perform multiple job driven by variations in terms of mix and volume requirements. Categorization of manufacturing flexibilities measures at operational level are equipment, material, routing and labour flexibilities (Koste and Malhotra, 1999).

\section{Material Handling Flexibility}

As one of the most resource consuming for reducing non-value added operational activities, material handling is often a bottleneck in a frequently changing demand mix in a manufacturing system that causing the waiting, moving, loading and unloading activities to constitute the major portion of the shop flow time (Deniz and Umit, 2012). In general, material handling flexibility (MHF) refers to "the amount of existing paths between processing centres and the heterogeneity (variety) of material, which can be transported along those paths without experiencing high transition penalties or large changes in performance outcomes" (Koste and Malhotra, 1999). Material handling flexibility is an operational level flexibility that is related to the individual elements or resources of the manufacturing system (Larso et. al., 2009). Oke (2013) further argued that material handling and machine flexibility are components of operation flexibility. However, according to Suarez et. al. (1996), material handling flexibility can be grouped to "lower-order" flexibility types, that fit into internal and flexibility phases of the value chain.

\section{Overview Importance of Integrating Flexibility in Manufacturing Firm}

There is a need for the study on the issues that the managers might face when implementing the flexibility in manufacturing organization. First, according to lonescu et. al. (2012), flexibility is critical attributes in business strategic planning; however, integration of manufacturing flexibility is treated as an isolated process instead as a part of firm's strategic management especially during new product development stage. In detail, new product development is a research and development (R\&D) activity that can sustain business growth and achieve competitive advantage over the competitors. Besides, Bhalla et. al. (2006) further explained that managerial engagements with no considerations of flexibility adjustments would led to organizations failures on intermediate and long term. Most E\&E manufacturing companies concentrate on deficiencies in quality and put little attention in incorporating flexibility in the manufacturing system (Gerwin, 1993) as the managers face difficult to develop or understand the concept (Larso et. al., 2009). Correa (1994) also addressed managers must comprehend the choices of flexibility and unplanned change control before justifying any business decisions. 


\section{New Product Performance}

Organizations seek for competitive advantage by performing better in term of performance (March and Sutton, 1997). Performance replicates the approach of an organization on exploiting both tangible and intangible resources to achieve its business goals (Wheelen and Hunger, 2010). According to Stanley and Canon (2012), the three common performance of new product are measured in term of: (1) Profitability of new products (Edward et. al., 2015; Paladino, 2007; Song and Thieme, 2006; Stanley, 2012) (2) New product sales revenue (Hanna et. al., 2015; Paladino, 2007) (3) New product success rate (Paladino, 2007; Song and Thieme, 2006; Stanley, 2012; Stanley, 2014) Larso et. al. (2009) categorized new product performance measurement that includes internal and external performance. Internal characterize performance focused on the measures within an organization (Kohli and Jaworski, 1990; Sanjaya et. al., 2011) while market orientated financial and sales measures is referred as external new product performance (Abdulai, 2011; Hussain et. al., 2015). Study on new product performance should consider both internal performance and external performance to be unidimensional measures that can contribution to new product performance. Both internal and external performance compromises a broader aspect of measurement such as product achievement through performance target and quality specification, measurement in terms of financial aspect and effectiveness of the project management through time-to-market of introduction of new product (Owee Kowang et. al., 2014).

\section{Hypotheses}

Hypotheses $\mathrm{H} 1, \mathrm{H} 2, \mathrm{H} 3, \mathrm{H} 4$ and $\mathrm{H} 5$ are postulated based on positive relationship between manufacturing flexibility dimensions (independent variable) and new product performance (dependent variable), where:

H1: New Product Flexibility has a positive relationship with New Product Performance.

H2: Operation Flexibility has a positive relationship with New Product Performance.

H3: Machine Flexibility has a positive relationship with New Product Performance.

H4: Labour Flexibility has a positive relationship with New Product Performance.

H5: Material Handling Flexibility has a positive relationship with New Product Performance. 
INTERNATIONAL JOURNAL OF ACADEMIC RESEARCH IN BUSINESS AND SOCIAL SCIENCES

Vol. 8, No. 12, Dec, 2018, E-ISSN: 2222-6990 @ 2018 HRMARS

Table 1 Chronological Summary of Manufacturing Flexibility Dimensions Sources

\begin{tabular}{ll}
\hline $\begin{array}{l}\text { Manufacturing } \\
\text { (MFD) }\end{array}$ & Flexibility \\
New Product & Literature Support \\
Operation & $3,4,6,7,10,11,13,14,15,16,17,18$ \\
Machine & $1,3,4,6,7,8,10,14,15$ \\
Labour & $1,2,3,4,5,6,7,10,14,18$ \\
Material Handling & $2,3,4,6,7,10,11,12,14$ \\
Capacity & $1,3,4,6,7,9,10,13,14,18$ \\
Expansion & $2,7,13,17$ \\
Process & $1,2,3$ \\
Production & 1,4 \\
Program/ Programming & 1,4 \\
Routing & $1,2,4$ \\
Market & $2,4,7,10$ \\
Modification & 1,4 \\
\hline
\end{tabular}

Source: 1- Sethi and Sethi (1990); 2- Hyun and Ahn (1992); 3- Koste and Malhotra (1999); 4- Vokurka and O'Leary-Kelly (2000); 5- Zubair et. al. (2001); 6- Koste et. al. (2004); 7- Larso et. al. (2009); 8Shellyanne and Ken (2010); 9- Deniz and Umit (2012); 10- Pankaj et. al. (2012); 11- Oke (2013); $12-$ Sawhney (2013); 13- Ainhoa et. al. (2014); 14- Fredriksson (2014); 15- He et. al. (2014); 16- Maike et. al. (2014); 17- Alavi (2016); 18- Mishra et. al. (2017)

\section{Methodology}

It is crucial for researcher to understand the philosophical perspective of the study so that the appropriate methodology can be selected (Holden and Lynch, 2004). Creswell (2009) used the term philosophical worldview or research paradigms as a basic set of beliefs that guide an action. The research adopted positivism for few reasons after considering the features of each research philosophies mentioned above. First, the variables discussed in this research have been widely and empirically investigated. Secondly, this research is a confirmatory research aimed to test the existing theories instead of exploring and developing new concept, hence, hypotheses were developed and tested based on resource-based theory (RBT). Next, the variables examined were reduced into small elements through operationalization so that they can be measured quantitatively. Lastly the researcher was independent of the subject being researched and large sample size were taken to generalize the findings. In this study, data were obtained mainly from primary sources. Questionnaire was used because quantitative data on the variables examined were needed for addressing the research questions and objectives of this study. 


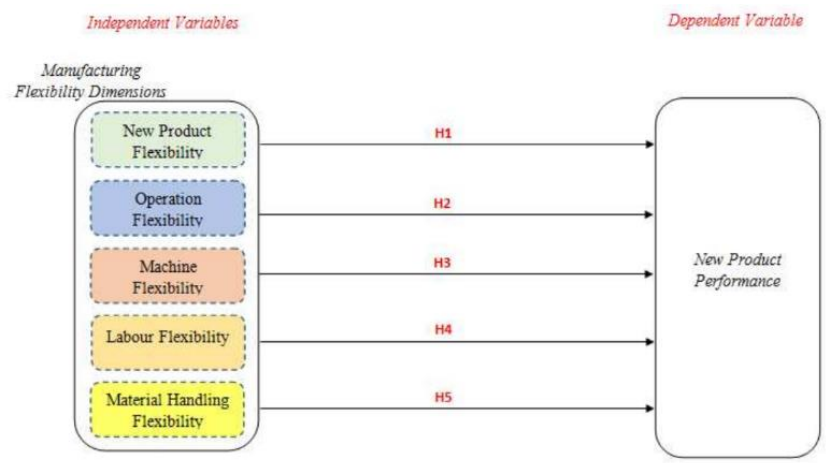

Figure $1 \quad$ Framework

\section{Results}

\section{Respondent Profile}

A total of 210 questionnaires was completed and returned. This led to an effective response rate of $63.25 \%$. Nevertheless, out of these responses, three questionnaires were rejected, as the respondent didn't complete the survey. No outliers were found in the analyses; hence, the total usable response rate was 207 (62.35\%). From the respondents' profile, majority of the respondents were middle management staff (75.4\%), and top management (24.6\%) consisted of senior managers/ presidents/ managing directors or chief executive officer (CEO) that are responsible for making the primary decisions within a company. In terms of primary job role, the respondents involved in quality management (35.3\%), supply chain management $(27.3 \%)$, operations management (15.5\%), R\&D (10.1\%), new product introduction (8.2\%) and sales \& product marketing (7.2\%). Based on the usable responses, most of the respondents working in electrical and electronics companies located in southern region of Peninsular Malaysia (41.5\%) followed by northern region (28.5\%), central region (17.9\%), Sabah and Sarawak (12.1\%).

\section{Descriptive statistics for variables}

To describe the fundamental elements of data, descriptive statistical analyses for independent variables, mediating variable and dependent variable are used, where the samples and measures are summarized. From the displayed result, means for all the constructs varied from 3.557 to 3.842 , with the standard deviation ranging 0.398 to 0.657 (Table 2).

Table 2 Descriptive Statistics for Variables

\begin{tabular}{lllllllll}
\hline & $\overline{\mathbf{x}}$ & SD & $\mathbf{1}$ & $\mathbf{2}$ & $\mathbf{3}$ & $\mathbf{4}$ & $\mathbf{5}$ & $\mathbf{6}$ \\
\hline LF & 3.72 & 0.62 & $\mathbf{0 . 7 3 4}$ & & & & & \\
MF & 3.77 & 0.53 & 0.438 & $\mathbf{0 . 8 3 4}$ & & & & \\
MHF & 3.81 & 0.64 & 0.203 & 0.293 & $\mathbf{0 . 7 7 1}$ & & & \\
NPF & 3.56 & 0.66 & 0.507 & 0.299 & 0.224 & $\mathbf{0 . 7 3 0}$ & & \\
NPP & 3.79 & 0.60 & 0.572 & 0.424 & 0.463 & 0.442 & $\mathbf{0 . 7 0 9}$ & \\
OF & 3.84 & 0.49 & 0.407 & 0.269 & 0.267 & 0.236 & 0.527 & $\mathbf{0 . 7 1 7}$ \\
\hline
\end{tabular}

Internal Consistency Reliability 
INTERNATIONAL JOURNAL OF ACADEMIC RESEARCH IN BUSINESS AND SOCIAL SCIENCES Vol. 8, No. 12, Dec, 2018, E-ISSN: 2222-6990 C 2018 HRMARS

Reliability is defined as the stability and consistency of measurement instrument. Cronbach's alpha was utilized to examine the inter-item consistency of the measurement items. Based on Hair et. al. (2010); Sekaran and Bougie (2013); Zikmund et. al. (2010), Cronbach's alpha coefficient is adequate to estimate the reliability of the measurement instrument. Sekaran and Bougie (2013) commented that the value of Cronbach's alpha is considered good when it is 0.80 , acceptable when it is 0.70 , poor when it is 0.60 and lower than 0.50 is substandard. Table 4.10 shows the reliability test result of the measurement instruments using Smart PLS 3.2.2. The results of the Cronbach's alpha values exceeded 0.70 , indicating the theoretical variables display a good internal stability and consistency. Hence, these results are consistent with the measures used in previous researches and the construct reliability was confirmed.

Table 3 Reliability Test Result of the Measurement Instruments

\begin{tabular}{|c|c|c|c|}
\hline Dimensions & Code & $\begin{array}{l}\text { Number of } \\
\text { items }\end{array}$ & Cronbach's Alpha Value \\
\hline Labour Flexibility & $\mathrm{LF}$ & 8 & 0.879 \\
\hline Machine Flexibility & MF & 4 & 0.854 \\
\hline Material Handling Flexibility & MHF & 8 & 0.901 \\
\hline New Product Flexibility & NPF & 8 & 0.877 \\
\hline New Product Performance & NPP & 8 & 0.858 \\
\hline Operation Flexibility & OF & 7 & 0.843 \\
\hline
\end{tabular}

\section{Construct Validity}

According to Beins and McCarthy (2012) construct validity is concerned with the capability of measurement in measuring the underlying concept that is supposed to be measured. Main objective of construct validity is to investigate the goodness of measurement items that are obtained from a sample represent the population's actual score (Hair et. al., 2010). Construct validity can be assessed by examining the indicator loadings (outer loadings and cross loadings). Each outer loading should be above 0.50 as criterion, indicating the items are significant and should be remained in the analysis. However, removing items from the measurement is required when outer loading values lower than 0.50. Detailed outer loadings and cross loadings data were shown in Appendix I. All loadings are above 0.50 , indicating that less than 50 percent of an indicator's variance was owing to error. In overall, all the indicators presented a satisfactory level of individual reliability and statistically significant. Accordingly, five items were removed from further analysis where the MF1, MF2, MF3, MF4 and OF8 values are lower than 0.50 . Table 4 below displayed the criteria for assessing construct validity. 
INTERNATIONAL JOURNAL OF ACADEMIC RESEARCH IN BUSINESS AND SOCIAL SCIENCES Vol. 8, No. 12, Dec, 2018, E-ISSN: 2222-6990 @ 2018 HRMARS

Table 4 Outer Loadings

\begin{tabular}{|c|c|c|c|c|c|c|}
\hline & LF & MF & MHF & NPF & NPP & OF \\
\hline LF1 & 0.742 & & & & & \\
\hline LF2 & 0.651 & & & & & \\
\hline LF3 & 0.723 & & & & & \\
\hline LF4 & 0.674 & & & & & \\
\hline LF5 & 0.759 & & & & & \\
\hline LF6 & 0.803 & & & & & \\
\hline LF7 & 0.749 & & & & & \\
\hline Lf8 & 0.764 & & & & & \\
\hline MF5 & & 0.790 & & & & \\
\hline MF6 & & 0.879 & & & & \\
\hline MF7 & & 0.808 & & & & \\
\hline MF8 & & 0.858 & & & & \\
\hline MHF1 & & & 0.677 & & & \\
\hline MHF2 & & & 0.674 & & & \\
\hline MHF3 & & & 0.743 & & & \\
\hline MHF4 & & & 0.754 & & & \\
\hline MHF5 & & & 0.846 & & & \\
\hline MHF6 & & & 0.850 & & & \\
\hline MHF7 & & & 0.819 & & & \\
\hline MHF8 & & & 0.784 & & & \\
\hline NPF1 & & & & 0.682 & & \\
\hline NPF2 & & & & 0.753 & & \\
\hline NPF3 & & & & 0.774 & & \\
\hline NPF4 & & & & 0.817 & & \\
\hline NPF5 & & & & 0.861 & & \\
\hline NPF6 & & & & 0.606 & & \\
\hline NPF7 & & & & 0.597 & & \\
\hline NPF8 & & & & 0.711 & & \\
\hline NPP1 & & & & & 0.683 & \\
\hline NPP2 & & & & & 0.695 & \\
\hline NPP3 & & & & & 0.755 & \\
\hline NPP4 & & & & & 0.659 & \\
\hline NPP5 & & & & & 0.757 & \\
\hline NPP6 & & & & & 0.775 & \\
\hline NPP7 & & & & & 0.668 & \\
\hline NPP8 & & & & & 0.665 & \\
\hline OF1 & & & & & & 0.664 \\
\hline OF2 & & & & & & 0.695 \\
\hline OF3 & & & & & & 0.773 \\
\hline OF4 & & & & & & 0.743 \\
\hline OF5 & & & & & & 0.724 \\
\hline OF6 & & & & & & 0.711 \\
\hline OF7 & & & & & & 0.706 \\
\hline
\end{tabular}


INTERNATIONAL JOURNAL OF ACADEMIC RESEARCH IN BUSINESS AND SOCIAL SCIENCES Vol. 8, No. 12, Dec, 2018, E-ISSN: 2222-6990 @ 2018 HRMARS

Table 5 Cross Loadings

\begin{tabular}{|c|c|c|c|c|c|c|}
\hline & LF & MF & MHF & NPF & NPP & OF \\
\hline LF1 & 0.742 & 0.169 & 0.095 & 0.332 & 0.381 & 0.355 \\
\hline LF2 & 0.651 & 0.181 & 0.104 & 0.365 & 0.364 & 0.303 \\
\hline LF3 & 0.723 & 0.266 & 0.121 & 0.307 & 0.356 & 0.357 \\
\hline LF4 & 0.674 & 0.173 & 0.121 & 0.292 & 0.304 & 0.304 \\
\hline LF5 & 0.759 & 0.378 & 0.258 & 0.460 & 0.507 & 0.292 \\
\hline LF6 & 0.803 & 0.443 & 0.193 & 0.375 & 0.457 & 0.282 \\
\hline LF7 & 0.749 & 0.402 & 0.219 & 0.476 & 0.448 & 0.257 \\
\hline Lf8 & 0.764 & 0.469 & 0.202 & 0.444 & 0.483 & 0.271 \\
\hline MF5 & 0.337 & 0.790 & 0.182 & 0.295 & 0.365 & 0.206 \\
\hline MF6 & 0.331 & 0.879 & 0.178 & 0.182 & 0.334 & 0.252 \\
\hline MF7 & 0.350 & 0.808 & 0.111 & 0.202 & 0.319 & 0.170 \\
\hline MF8 & 0.443 & 0.858 & 0.194 & 0.302 & 0.387 & 0.259 \\
\hline MHF1 & 0.156 & 0.104 & 0.677 & 0.143 & 0.333 & 0.197 \\
\hline MHF2 & 0.107 & 0.171 & 0.674 & 0.141 & 0.308 & 0.144 \\
\hline MHF3 & 0.167 & 0.133 & 0.743 & 0.082 & 0.363 & 0.250 \\
\hline MHF4 & 0.120 & 0.166 & 0.754 & 0.155 & 0.329 & 0.156 \\
\hline MHF5 & 0.144 & 0.170 & 0.846 & 0.177 & 0.356 & 0.177 \\
\hline MHF6 & 0.236 & 0.163 & 0.850 & 0.221 & 0.353 & 0.176 \\
\hline MHF7 & 0.253 & 0.173 & 0.819 & 0.223 & 0.416 & 0.266 \\
\hline MHF8 & 0.215 & 0.165 & 0.784 & 0.211 & 0.381 & 0.258 \\
\hline NPF1 & 0.496 & 0.343 & 0.148 & 0.682 & 0.437 & 0.312 \\
\hline NPF2 & 0.362 & 0.144 & 0.105 & 0.753 & 0.258 & 0.181 \\
\hline NPF3 & 0.401 & 0.201 & 0.226 & 0.774 & 0.323 & 0.124 \\
\hline NPF4 & 0.412 & 0.227 & 0.187 & 0.817 & 0.355 & 0.133 \\
\hline NPF5 & 0.463 & 0.229 & 0.189 & 0.861 & 0.399 & 0.225 \\
\hline NPF6 & 0.239 & 0.150 & 0.105 & 0.606 & 0.192 & 0.064 \\
\hline NPF7 & 0.220 & 0.096 & 0.115 & 0.597 & 0.157 & 0.017 \\
\hline NPF8 & 0.297 & 0.214 & 0.207 & 0.711 & 0.293 & 0.134 \\
\hline NPP1 & 0.351 & 0.189 & 0.291 & 0.285 & 0.683 & 0.418 \\
\hline NPP2 & 0.366 & 0.227 & 0.341 & 0.261 & 0.695 & 0.405 \\
\hline NPP3 & 0.369 & 0.304 & 0.269 & 0.222 & 0.755 & 0.533 \\
\hline NPP4 & 0.335 & 0.261 & 0.291 & 0.162 & 0.659 & 0.433 \\
\hline NPP5 & 0.406 & 0.408 & 0.418 & 0.334 & 0.757 & 0.385 \\
\hline NPP6 & 0,407 & 0.377 & 0.327 & 0.320 & 0.775 & 0.364 \\
\hline NPP7 & 0.513 & 0.295 & 0.356 & 0.458 & 0.668 & 0.204 \\
\hline NPP8 & 0.491 & 0.319 & 0.318 & 0.465 & 0.665 & 0.246 \\
\hline OF1 & 0.383 & 0.220 & 0.102 & 0.280 & 0.365 & 0.664 \\
\hline OF2 & 0.232 & 0.187 & 0.093 & 0.194 & 0.362 & 0.695 \\
\hline OF3 & 0.296 & 0.241 & 0.184 & 0.199 & 0.381 & 0.773 \\
\hline OF4 & 0.314 & 0.219 & 0.209 & 0.206 & 0.342 & 0.743 \\
\hline OF5 & 0.385 & 0.198 & 0.330 & 0.141 & 0.435 & 0.724 \\
\hline OF6 & 0.217 & 0.167 & 0.194 & 0.106 & 0.381 & 0.711 \\
\hline OF7 & 0.189 & 0.116 & 0.186 & 0.068 & 0.360 & 0.706 \\
\hline
\end{tabular}


INTERNATIONAL JOURNAL OF ACADEMIC RESEARCH IN BUSINESS AND SOCIAL SCIENCES Vol. 8, No. 12, Dec, 2018, E-ISSN: 2222-6990 C 2018 HRMARS

Partial least squares (PLS) are SEM techniques, which based on an iterative approach that maximizes the explained variance of endogenous construct (Hair et. al., 2014). After analysing the goodness of measurement instruments, PLS-SEM techniques are adopted in assessing the quality of structural model. The coefficient of determination is the preliminary assessment criterion of structural model that refers to the measure of model's predictive accuracy and is calculated as the squared correlation between a specific endogenous construct's actual and predicted values (Hair et. al., 2014). It provides an explainable variation in the total variation to the equation. Assessment results of coefficient of determination are displayed in Figure 2. For first-order constructs, the $R^{2}$ of sustainable competitive advantages (SCA) was 0.428 , where $42.8 \%$ variance was explained by labour flexibility (LF), machine flexibility (MF), material handling flexibility (MHF), new product flexibility (NPF) and operation flexibility (OF). Next, the $R^{2}$ of new product performance (NPP) was 0.593 , where $59.3 \%$ variance was explained by labour flexibility (LF), machine flexibility (MF), material handling flexibility (MHF), new product flexibility (NPF), operation flexibility (OF) and sustainable competitive advantages (SCA). For second-order constructs, $R^{2}$ of sustainable competitive advantages (SCA) was 0.390 , where $39.0 \%$ variance was explained by manufacturing flexibility (MFD).

Table 6 Cross Coefficient of Determination for First-Order Constructs

\begin{tabular}{lllll}
\hline Dimensions & Code & $R^{2}$ & Redundancy & AVE \\
\hline Labour Flexibility & LF & Predictor & Predictor & 0.539 \\
Machine Flexibility & MF & Predictor & Predictor & 0.696 \\
Material Handling Flexibility & MHF & Predictor & Predictor & 0.594 \\
New Product Flexibility & NPF & Predictor & Predictor & 0.533 \\
New Product Performance & NPP & $0.593^{* * *}$ & 0.091 & 0.502 \\
Operation Flexibility & OF & Predictor & Predictor & 0.514 \\
\hline
\end{tabular}

Legend: $R^{2}>0.32$ (Substantial)***,

$R^{2}>0.15$ (Moderate)**,

$R^{2}>0.02($ Weak)*

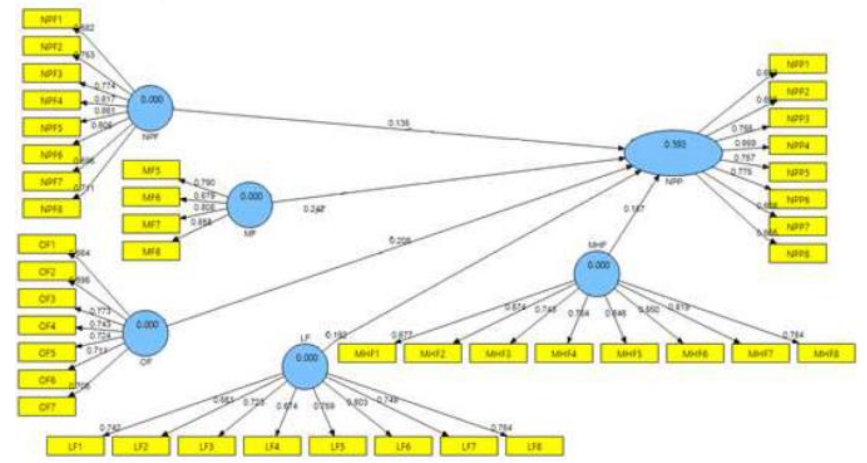

Figure 2 Assessment Results of Coefficient of Determination 
INTERNATIONAL JOURNAL OF ACADEMIC RESEARCH IN BUSINESS AND SOCIAL SCIENCES Vol. 8, No. 12, Dec, 2018, E-ISSN: 2222-6990 @ 2018 HRMARS

\section{Discussion and Findings}

Generally, based on the comprehensive literature review, most study on flexibility was conducted in developed countries (Larso et. al., 2009; Zubair et. al., 2001), and further pragmatic research concerning manufacturing flexibility is vital to be conducted in emerging countries (Ruchi et. al., 2014) such as Malaysia. New product performance is the measure of internal such as product quality, timeto-market and cost, and, external performance (market orientation and sales-based measurement) in the process of transforming innovative concepts into products (Larso et. al., 2009; Stanley and Canon, 2012). Besides, manufacturing industries in northern region of Malaysia faced dynamic changes as one of the fast growing international manufacturing industrial hubs for new product development. The statistical outputs from multivariate analyses examined the manufacturing flexibility and new product performance have found that positive and significant effect on the hypothesized relationships. Based on the underlying theory of dynamic capabilities, organization that is competent to deploy relevant types of internal capabilities (such as manufacturing flexibility) are able to achieve better new product performance by offering new products to emerging customers. Aim of the research is to examine the associations between the manufacturing flexibility and its dimensions (new product flexibility, operation flexibility, machine flexibility, labour flexibility and material handling flexibility) with new product performance. According to the research findings, all the six hypotheses in relation with the manufacturing flexibility and its dimensions with new product performance were statistically significant, indicating the manufacturing flexibility was positively associated to new product performance.

New product flexibility was positively significant to new product performance with the reliability of 0.877 . Hypotheses 1 was fully supported. Additionally, the outcome of the hypothesis is consistent with the previous researches such as Fantazy and Salem (2016); Minkyun et. al. (2014). These results of all significant positive association between new product flexibility and new product performance was expected since efficiency of flexibility integration within the organization will enhance the success rate and performance of NPD projects (Heiner et. al., 2014). In this study, operation flexibility was found positively significant to new product performance with the reliability of 0.843 , representing hypothesis 2 was fully supported. According to Larso et. al. (2009), a manufacturing organization could achieve higher flexibility in new products by paying focuses on operation flexibility at the shop-floor level. The finding is aligned with the past study carried out by Pankaj et. al. (2012) in uncertain operations environment. Machine flexibility has tendency to support all the product performance. Although Larso et.al. (2009) showed negative correlation between machine flexibility and new product performance, in this study, positive and significant relationship exhibited in machine flexibility and new product performance with the reliability of 0.854 . Hypothesis 3 was fully supported. The findings indicated that new product performance are susceptible to machine flexibility, which therefore are expected to achieve superior success of new product performance in the measures of internal and external perspectives. Labour flexibility was positively significant to new product performance with the reliability of 0.879 . Hypothesis 4 was supported. This indicated that labour flexibility is critically crucial in boosting the performance of new product development in electrical and electronics industries in Malaysia (Ajai et.al., 2013). The findings are consistent with the previous researches conducted by Chang, (2012); Narain et. al. (2000); Suarez et. 
al. (1996). In general, build material handling flexibility is suggested to attain positive impact on performance (Larso et.al., 2009). Koste et. al., 2004; Pankaj et. al. (2012) also confirmed the positive association between material handling flexibility and new product performance. Positive and significant relationship exhibited in machine flexibility and new product performance with the reliability of 0.901 . Hence, this indicated hypothesis 5 was fully supported.

\section{Contribution of the Study}

Present research studied the dimensions of manufacturing flexibility as element of organizational capabilities in representing the concept of dynamic capabilities, has contributed to a better understanding on the effects of these capabilities on new product performance. Manufacturing flexibility served as backbone to the catalysis of the product development capabilities and performance enhancement for Malaysian electrical and electronics manufacturing industries (Luis et. al., 2015). Thus, it is imperative to integrate flexibility in manufacturing industry to sustain competitive advantages and product development performance in facing the fourth industrial revolution in near future.

\section{Theoretical Contribution}

Former research conducted by Acur et. al. (2010), relationships between dynamic capabilities and performance had been largely disregarded in the context of new product development. Hence, this research will develop the concept of dynamic capabilities, which is considered relatively uncharted. The foundation of the research framework was based on the theory of dynamic capability that viewed internal capabilities in facilitating organization's flexibility to sustain competitive advantages and achieve higher performance. In general, this research provided several theoretical contributions to the theory of dynamic capabilities. Besides, this research has left implication to the theory of dynamic capability by building up new product success model for flexibility implementation in Malaysia E\&E manufacturing industry, which can serve as the guiding principle for educators and practitioners. Larso et. al. (2009) also further mentioned that the integrated organizational capability such as flexibility that is hard to be imitated by rivals, can help to sustain organizational competitive advantages, as it is the source of heterogeneity between firms that cause differences in performance.

\section{Practical Contribution}

Besides, the research findings suggested several practical implications. This research may serve as a managerial guide in enhancing organizational capabilities in new product development. First, practitioners can attain flexibility in their manufacturing system when developing more products. This would enable managers to focus on the most significant predictors of performance while facilitating flexibility in manufacturing system to sustain competitive advantages. In other words, it remunerates the shareholders by recognizing the key features for a company's success in new product development. From a pragmatic perspective, the propositions of this research is not only restricted to electrical and electronics manufacturing industries context, but can be referred by other manufacturing industries such as oil and gas or food manufacturing companies. Hence, the findings of this research would enable the firm's decision makers to develop strategy that able to sustain 
INTERNATIONAL JOURNAL OF ACADEMIC RESEARCH IN BUSINESS AND SOCIAL SCIENCES

Vol. 8, No. 12, Dec, 2018, E-ISSN: 2222-6990 @ 2018 HRMARS

better performance over the rivals in this highly competitive and dynamic external business environment.

\section{Methodological Contribution}

As theories in dynamic capabilities research become more nuanced, it becomes more necessary to adopt methodology that is capable of handling more complex model structures. Present study applied the Partial least square SEM (PLS-SEM) analysis as methodological contribution in promoting better quality and providing useful features of research with more accurate results especially on multivariate modelling methods. The application of Structural Equation Modelling would promote better quality features of research with more accurate results, especially in modelling of quantitative multivariate methods. In addition, the study would significantly contribute to the methodological perspective by establishment of empirical dimensionality, validity and reliability of instruments measured in the Malaysia electrical and electronics industry context. Besides, PLS-SEM is capable of handling data inadequacies such as non-normal data (Sarstedt et.al., 2014). In addition, the analysis of mediating relationships in the PLS path model augmented the insights of the relationships between the constructs as it delved deeper into the cause and effect of these relationships, indicating the strength of direct and indirect effects. These rich findings would lead to the refinement or expansion of new models or theories in new product development and related disciplines. Another stream of methodological research of PLS-SEM deals with complex constructs that are operationalized at higher levels of abstraction.

\section{Limitations and Further Research}

This study presented empirical evidence that contributed to the knowledge of performance in new product development; however, these research findings were interpreted within the limitations of study. While recognizing the constraints of the analyses, these limitations offer some opportunities for future research. Firstly, the study was constrained by the limited data collection duration. In addition, the constraints in data collection may due to limited cooperation from the respondents, which was caused by firm policy, uncompleted survey from the respondents. While present research provides an important and significant insight into study on manufacturing flexibility and new product performance in electrical and electronics industries in Malaysia, it also offers several promising avenues for further research. Limitations and constraints of the current study have created opportunities for prospect researches. Future researches could be conducted through qualitative or quantitative approaches to obtain further understanding on the relationships of manufacturing flexibility, sustainable competitive advantages and new product performance. As new product performance may vary due to different factors, future study can be expanded on other antecedent factors to obtain new insights related to this research.

Based on Ang (2008), even though different manufacturing industries are facing same level of competitive intensity, but they have different opportunities in different technology industries. As such, future study is recommended to focus on the specific industries where similarities and dissimilarities in deployment of manufacturing flexibilities can be meaningfully identified. This occurred due to same capabilities may differ at the explorative level from other segmentation of 
manufacturing firm. Thirdly, there are still unknown in electrical and electronics industries in Malaysia whether presence of moderating variables could influence the relationship of manufacturing flexibility and new product performance framework. Hence, future research should consider the moderating effect such as environmental dynamism in the present study framework. Next, while manufacturing flexibility dimensions are sensational at improving the new product performance of an organization, but some of the manufacturing flexibility dimensions are not statistically significant. Accordingly, future research should consider re-examination on the relationship between manufacturing flexibility and new product performance.

\section{Corresponding Author}

BakAun Teoh

School of Technology Management and Logistics

College of Business, Universiti Utara Malaysia, Sintok 06010 Kedah Malaysia

E-mail: teoh_bak@oyagsb.uum.edu.my

\section{References}

Abdulai, M. M. (2011). Market Orientation and Business Performance among SMEs in Ghana. International Business Research, 4(1), 241-251.

Abdulkareem, S. A., Adel, A. A., \& John, R. A. (2013). Competitive Priorities and Competitive Advantage in Jordanian Manufacturing. Journal of Social Science and Management, 6, 69-79.

Acur, N., Kandemir, D., Weerd-Nederhof, P. C., \& Song, M. (2010). Exploring the Impact of Technological Competence Development on Speed and NPD Program Performance. Journal of Product Innovation Management, 27(6), 915-929. DOI: 10.1111/j.1540- 5885.2010.00760.x

Adegoke, O. (2005). A framework for analysing manufacturing flexibility. International Journal of Operations \& Production Management, 25(10), 973 - 996.

Ajai, J., Jain, P. K., Felix Chan, T. S., \& Shailendra. (2013). A review on manufacturing flexibility. International Journal of Production Research, 51, 5946-5970.

Alan, C., Marek, S., \& Mike, S. (2009). A process for managing manufacturing flexibility. International Journal of Operations \& Production Management, 29(4), 357 - 385.

Alka, A. N., Prakash, J. S., \& Damien, P. (2013). Testing an integrated model of operations capabilities. International Journal of Operations and Production Management, 33(7), 887-911.

Ang, S. H. (2008). Competitive Intensity and Collaboration: Impact on Firm Growth Across Technological Environments. Strategic Management Journal, 20, 1057-1075.

Art, K. W., Norman, P. M., Hatfield, D. E., \& Cardinal, L. B. (2010). A longitudinal study of the impact of R\&D, patents and product innovation on firm performance. Journal of Product Innovation Management, 27, 725-740.

Benjaafar, S. (1994). Models for performance evaluation of flexibility in manufacturing systems. International Journal of Production Research, 32(6), 1383-1402.

Berman, K., \& Sami, K. (2005). The Supplier and Customer Contribution to Manufacturing Flexibility: Australian Manufacturing Industry's Perspective. Journal of Manufacturing Technology Management, 16(7), 733-752. 
INTERNATIONAL JOURNAL OF ACADEMIC RESEARCH IN BUSINESS AND SOCIAL SCIENCES

Vol. 8, No. 12, Dec, 2018, E-ISSN: 2222-6990 @ 2018 HRMARS

Bhalla, A., Henderson, S., \& Watkins, D. (2006). A Multiparadigmatic Perspective of Strategy. International Small Business Journal, 24(5), 515-537.

Brill, D., \& Mandelbaum, M. (1990). Measurement of adaptivity and flexibility in production systems. European Journal of Operational Research, 49, 325-332.

Browne, J., Dubois, D., Rathmil, K., \& Sethi, S. P. (1984). Classification of flexible manufacturing systems. FMS Magazine, 2(2), 114-117.

Cesar, C., \& Ana, V. L. (2010). An examination of the relationship between manufacturing flexibility and firm performance The mediating role of innovation. International Journal of Operations \& Production Management, 30(8), 853-878. DOI: 10.1108/01443571011068199

Chandrashekar, A. (1994). A Study of some of the Trade-offs Affecting Manufacturing Flexibility. Arizona State University: Doctoral Dissertation.

Chryssolouris, G. (1996). Flexibility and Its Measurement. Annals of CIRP, 45(2), 581-587.

Correa, H. L. (1994). Linking Flexibility, Uncertainty and Variability in Manufacturing Systems: Managing Unplanned Change in the Automotive Industry. Aldershot: Avebury.

Deniz, K., \& Umit, B. (2012). Material handling considerations in the FMS loading problem with full routing flexibility. International Journal of Production Research, 50(22), 6530- 6552. DOI: 10.1080/00207543.2011.653837

Dess, G. G., \& Beard, D. W. (1984). Dimensions of organizational task environments. Administrative Science Quarterly, 29(1), 52-73.

D'Souza, D. E., \& Williams, F. P. (2000). Towards a taxonomy of manufacturing flexibility dimensions. Journal of Production Research, 18, 577-593.

Edward, C. S., Wu-Chung, W., \& Yan, J. C. (2015). The relationships among supply chain partnerships, customer orientation and operational performance: the effect of flexibility. Information Systems and e-Business Management.

Fantazy, K. A., \& Salem, M. (2016). The value of strategy and flexibility in new product development: The impact on performance. Journal of Enterprise Information Management, 29(4), 525-548. DOI:10.1108/JEIM-10-2014-0102

Gerwin, D. (1993). Manufacturing Flexibility: A Strategic Perspective. Management Science, 39(4), 395-410.

Heiner, E., Martin, E., \& Roger, J. C. (2014). Success Factors of Product Innovation: An Updated MetaAnalysis. Journal of Product Innovation Management, 29(10), 21-37.

Hussain, J., Ismail, K., \& Ali Shah, F. (2015). The Effect of Market and Entrepreneurial Orientations on Organizational Performance. City University Research Journal, 5(2), 203-218.

Ilker, M. A., \& Birdogan, B. (2011). Antecedents and performance impacts of product versus process innovation: Empirical evidence from SMEs located in Turkish science and technology parks. European Journal of Innovation Management, 14(2), 172-206.

Ionescu, V. C., Cornescu, V., \& Druica, E. (2012). Flexible Organization. Global Business and Management Research: An International Journal, 4(3), 277-285.

Kohli, A. K., \& Jaworski, B. J. (1990). Market orientation: the construct, research propositions, and managerial implications. Journal of Marketing, 54(2), 1-18.

Koste, L. L., \& Malhotra, M. K. (1999). A Theoretical Framework for Analyzing the Dimensions of Manufacturing Flexibility. Journal of Operations Management, 18, 75-93. 
INTERNATIONAL JOURNAL OF ACADEMIC RESEARCH IN BUSINESS AND SOCIAL SCIENCES Vol. 8, No. 12, Dec, 2018, E-ISSN: 2222-6990 @ 2018 HRMARS

Larso, D., Doolen, T., \& Hacker, M. (2009). Development of a manufacturing flexibility hierarchy through factor and cluster analysis: The role of new product type on US electronic manufacturer performance. Journal of Manufacturing Technology Management, 20(4), 417-441.

Lim, S. H. (1987). Flexible manufacturing systems and manufacturing flexibility in the United Kingdom. International Journal of Operations and Production Management, 7(6), 44-54.

Maike, S. R., Patricia, D., \& Gopesh, A. (2014). Manufacturing Flexibility through outsourcing: effects of contingencies. International Journal of Operation and Production Management, 34(9), 12101242.

Malaysia Competitiveness Index 2007-2015. (2015, October 22). Retrieved from Trading Economics: http://www.tradingeconomics.com/malaysia/competitiveness-index

March, J. G., \& Sutton, R. J. (1997). Crossroads-organizational performance as a dependent variable. Organization Science, 8(6), 698-706.

Mikell, P. G. (2007). Fundamentals of Modern Manufacturing: Materials, Processes, and Systems. New Jersey: John Wiley and Sons (Asia) Pte Ltd.

Mills, J., Platts, K., \& Bourne, M. (2003). Applying resource-based theory: methods, outcomes and utility for manages. International Journal of Operations \& Production Management, 23(2), 148-66.

Minkyun, K., Nallan, C. S., \& Canan, K. H. (2014). An impact of manufacturing flexibility and technological dimensions of manufacturing strategy on improving supply chain responsiveness: Business environment perspective. International Journal of Production Research, 51, 5597-5611.

Nakata, C., Im, S., Park, H., \& Ha, Y. W. (2006). Antecedents and consequence of Korean and Japanese new product advantage. Journal of Business Research, 59(1), 28-36.

NCIA. (2009). Come North: Expand Business Boundaries. Penang: Northern Corridor Implementation Authority (NClA).

Northern Corridor Economic Region. (2015, September 4). Retrieved from Malaysian Administrative Modernisation and Management Planning Unit (MAMPU): http://www.mycorridor.malaysia.gov.my/IC/NCER/Pages/default.aspx

Oke, A. (2013). Linking manufacturing flexibility to innovation performance in manufacturing plants. International Journals of Production Economics, 143, 242-247. DOI: 10.1016/j.ijpe.2011.09.014

Owee Kowang, T., Amran, R., \& Sang Long, C. (2014). New Product Development in Malaysia: Does Organizational Background Really Matter? Jurnal Teknologi (Sciences \& Engineering), 68(3), 113117.

Paladino, A. (2007). "Investigating the drivers of innovation and new product success: a comparison of strategic orientations. Journal of Product Innovation Management, 24(6), 534-553.

Pankaj, P. C., Siri, T., \& Dan, L. (2012). Enhancing effects of manufacturing flexibility through operational absorptive capacity and operational ambidexterity. Journal of Operations Management, 30, 201-220. doi:10.1016/j.jom.2011.10.004

Roger, W. S., \& Mohan, V. T. (2005). Manufacturing Process Flexibility Revisited. International Journal of Operations and Product Management, 25(12), 1183-1189. doi:10.1108/01443570510633585

Ruchi, M., Ashok, K., Pundir, L., \& Ganapathy. (2014). Assessment of manufacturing flexibility. Management Research Review, 37(8), 750-776. 
INTERNATIONAL JOURNAL OF ACADEMIC RESEARCH IN BUSINESS AND SOCIAL SCIENCES

Vol. 8, No. 12, Dec, 2018, E-ISSN: 2222-6990 @ 2018 HRMARS

Sanjaya, S. G., Hari, V., \& Ajai, S. G. (2011). Market orientation and manufacturing performance of Indian SMEs: Moderating role of firm resources and environmental factors. European Journal of Marketing, 44(7/8), 1172-1193.

Sari, W., Alia, N. A., \& Anom, J. S. (2012). The Key Success Factors of Penang as Silicon Valley of the East. SBS Journal of Applied Business Research, 1, 1-18.

Sarstedt, M., Ringle, C. M., Smith, D., \& Reams, R. (2014). Partial Least Squares Structural Equation Modeling (PLS-SEM): A Useful Tool for Family Business Researches. Journal of Family Business Strategy. DOI: 10.1016/j.jfbs.2014.01.002

Schmenner, R. W., \& Tatikonda, M. V. (2005). Manufacturing process flexibility revisited. International Journal of Operations \& Production Management, 25(12), 1183-1189. doi:10.1108/01443570510633585

Sethi, A. K., \& Sethi, S. P. (1990). Flexibility in Manufacturing: A Survey. The International Journal of Flexible Manufacturing Systems, 2, 289-328.

Shewchuk, J. P. (1999). A Set of Generic Flexibility Measures for Manufacturing Applications. International Journal of Production Research, 37(13), 3017-42.

Slack, N. (1991). The Manufacturing Advantage. London: Mercury Business Books.

Song, M., \& Thieme, R. J. (2006). A cross-national investigation of the R\&D-marketing interface in the product innovation process. Industrial Marketing Management, 35(3), 308-322.

Stanley, W. (2014). Impact of environmental turbulence on entrepreneurial orientation and new product success. European Journal of Innovation Management, 17(2), 229-249.

Stanley, W. K. (2012). The influences of entrepreneurial orientation on product advantage and new product success. Journal of Chinese Entrepreneurship, 4(3), 243-262.

Stanley, W. K., \& Canon, T. (2012). The Influence of Market Orientation on New Product Success. European Journal of Innovation Management, 15(1), 99-121.

Suarez, F. F., Cusumano, M. A., \& Fine, C. F. (1996). An empirical study of manufacturing flexibility in printed circuit board assembly. Operations Research, 44(1), 223-240.

Wheelen, T., \& Hunger, D. (2010). Strategic Management and Business Policy. Upper Saddle River, USA: Pearson Prentice Hall.

Zhang, Q., Vonderembse, M., \& Lim, J. (2003). Manufacturing flexibility: defining and analyzing relationships among competence, capability, and customer satisfaction. Journal of Operations Management, 2, 173-191.

Zubair, M. M., Mohamed, A. Y., \& Faizul, H. (2001). The impact of machine flexibility on the performance of flexible manufacturing system. International Journal of Operations \& Production Management, 21(5/6), 707-742. 